\title{
Pristiphora Abietina Christ., Defoliator in Resinous Forest Stands of Lunca Bradului Forestry Department
}

\author{
Ion OLTEAN ${ }^{1)}$, Alexandru BEXA ${ }^{1)}$, Teodora FLORIAN ${ }^{1)}$, Mircea Ioan VARGA ${ }^{1)}$ \\ 1) Department of Environment and Plant Protection. University of Agricultural Sciences and Veterinary \\ Medicine Cluj-Napoca, Romania. \\ ${ }^{*}$ Corresponding author, e-mail: varga_mrc@yahoo.com
}

Bulletin UASVM Horticulture 71(2) / 2014

Print ISSN 1843-5254, Electronic ISSN 1843-5394

DOI:10.15835/buasvmcn-hort:10609

\begin{abstract}
Pristiphora abietina Christ. is one of the most dangerous pest of coniferous forest stands, especially in those that are located outside their natural vegetation area. During four years this specie was monitored in Lunca Bradului Forestry Department and it has been found that there is a trend of reduceing of the infested areas and of the degree of infestation. Infested area decreased from 2.85\% (in 2010) to $0.39 \%$ (in 2013) of the total area of the Forestry Department. As a result of soil surveys it was found that larval hibernating density ranged from: 1.3 to 25.2 larvae $/ \mathrm{m}^{2}$ (in 2010, from 1.2 to 6.5 larvae $/ \mathrm{m}^{2}$ (in 2011), between 1.1 to 2.9 larvae / $\mathrm{m}^{2}$ (in 2012), and between 1.1 to 2.2 larvae $/ \mathrm{m}^{2}$ (2013). This trend is determined both by the action of chemical control of larvae and due to the contribution of useful entomofauna. In this infested stands, we proceeded to multiplying the ant mounds. Entomofauna of predatory Carabidae collected in Barber traps is represented by 36 species. The dominant species are: Carabus ulrichii Germar. and Harpalus distinguendus Duft.
\end{abstract}

Keywords: Monitoring, Pristiphora abietina Christ., soil survey, Barber traps, Carabidae

\section{INTRODUCTION}

From the rich complex of pests affecting the health of trees in coniferous forests, defoliators show a significant economic importance. Pest species always act in complex, but the importance of each species differs from a forest to another and from one year to another, this fact being correlated with the particular pedo-climatic zone, with the useful entomofauna actions and with the protection management of the forest (Holuša et al., 2005, 2006; Wulf and Schumacher, 2007; Perepechina, 2010; Tãut et al., 2011).

The specie Pristiphora abietina Christ. was reported for the first time in Europe in 1862 on Picea abies. Small Spruce Sawfly is a dangerous pest and creates major problems in coniferous stands in all European countries (Holuša and Drápela, 2006; Holuša and Lubojacký, 2007). In our country in the last years it has spread with great rapidity and it raises important issues regarding the protection of spruce located outside natural vegetation area (Tăut et al, 2011). It is a pest that causes damage in spruce stands situated on sunny slopes, situated in places without strong air currents in dominant trees. It is also very common in the places where spruce is found outside the natural range of vegetation (Holonec et al., 2004).

The strongest attacks are encountered in stands located at low altitudes, usually at altitudes up to $700 \mathrm{~m}$ (Netherer and Fuhrer, 1999; Holuša and Holuša, 2003). The most attacked are the plantations aged 10 to 30 years. The harmful gradations of this insect are the less frequent and they occur mainly in artificial stands established outside the natural range of spruce. The species is monovoltin and overwinters in soil in the larval stage. The puppation is observed in the spring.

The flight of adults takes place in spring, during April-May, with the maximum flight curve in the first decade of May and the incubation lasts about 5 days.

The larvae are living clustered, chewing together the needles that are chewed starting from the top. The larvae, during their development, 
spread a characteristic odor similar to the stink bugs. In June the larvae descends in litter or moss layer, sometimes even in the soil at a depth of 2-3 $\mathrm{cm}$, which housed in a hard cocoon are preparing for summer diapause wich continues with the hiemal diapause in the cold season (Holuša, 1999).

There were identified 38 species of predatory species for Pristiphora abietina Christ., of which 34 are insects and mites and the remaining are birds and mammals. Among the predatory insects most important have proved to be: Pterostichus oblongopunctatus F., Athous subfuscus Mull., Troilus luridus F., Panorpa communis L., Formica polyctena şi Panorpa communis, Calosoma sycophanta, Anatis ocellata, Triolus luridus, Syrphus tricinetus, Athous subfuscus, Formica rufa (Ionaitis and Zayanchkauskas 1973; Egger,1989, 1990).

The predatory Carabidae species also have an important role in reducing the pest biological reserves. The structure and abundance of carabid populations are influenced by the existing vegetation stands. In general the vegetation cover is influenced by altitude, slope aspect and stand age (Schmied and Fuhrer, 1996).

Schmied and Führer (1996) found 18 natural parasites for Pristiphora abietina Christ. of which the most active are: Ctenochira flavicauda si Ichneutes reunitor Ness., but also an important contribution was given by the species: Aptesis nigrocincta, Phaeogenes sp., Microcryptus sp., Pimpla sp. Endasys euxestus and Oresbius bipunctatus.

The aim of this paper was the monitoring of Pristiphora abietina Christ. specie in six production units from Lunca Bradului Forestry Department and the evaluation of the population density during 2012-2013.

\section{MATERIALS AND METHODS}

The forest stands of Lunca Bradului Forest District are located in the north-eastern part of Mures County, on the upper course of the river Mures having a surface of 24373 ha.

The forest fund is divided into six production units (P.U.). The levels of vegetation are the FM2 (mountain mixtures) at a rate of $82 \%$ and FM3 (mountain spruce forests) at a rate of $18 \%$. For assessing the areas of resinous stands damaged by Pristiphora abietina Christ. during May and June all surfaces where the presence of attack was reported were detected. On the infested surfaces we have evaluated the population density, by making soil surveys under the projection of the crown, where the larvae sheltered for diapause were counted. For this action, in the last decade of August or the first days of September, in each infested plot were randomly chosen three trees, evenly spaced in the parcel at which have been made three soil surveys, at the depth of $10 \mathrm{~cm}$.

At each secondary production unit (s.p.u.) where the attack was reported, its entire infested surface was calculated, as shown in the management plan. for the monitoring of the carabid fauna in the forest stands, Barber traps were placed and for each trap were made eight observations. The collection of Carabidae species was conducted annually between the months of May to September and all the collected specimens were identified.

\section{RESULTS AND DISCUSSION}

In the Lunca Bradului Forestry Department the specie Pristiphora abietina Christ. was reported in all the production units. In 2010 the infested area was 494 ha, located in 108 sites which represent $2.03 \%$ of the total Forest District. At the production unit level the percentage of infested areas was between $0.9 \%$ (in P. U. IV) and $4.4 \%$ (in P. U. V, unit where the stands with conifers are at the lowest altitude). In the case of the surveys conducted under the projection of trees the monitored larval density ranged from 1.3 larvae $/ \mathrm{m}^{2}$ to 25.6 larvae $/ \mathrm{m}^{2}$.

The surfaces where the intensity of the attack was powerful are located in P.U.I Ilva and in P.U. III Neagra, in P U.II Ilişoara and P.U. IV Gudea has been reported a medium intensity attack on the some surfaces.

The average density of viable cocoons in the soil / sqm found by Brudea and Pei (2006) was 24 cocoons in 2003, 23 in 2004 and 19 in 2005.

In 2011, given that the previous year was reported as medium or with strong attack on some surfaces, when hibernating larvae have restarted, it was applied a chemical treatment with synthetic pyrethroids.

In this year the attack of this species has been reported on a surface of 441 ha, situated in 92 s.p.u, representing $1.81 \%$ of the total forest. At the level of P. U. the proportion of infested areas was between $1.1 \%$ in U.P. IV and $4.9 \%$ P.U. V. When evaluating the average number of larvae reported in a square meter in the projection of a tree, it ranged from 1.2 larvae $/ \mathrm{m}^{2}$ to 6.5 larvae $/ \mathrm{m}^{2}$. These data are in 
Tab. 1. The situation of infested areas with Pristiphora abietina Christ. and the density of hibernating larvae (Lunca Bradului, 2010 - 2013)

\begin{tabular}{|c|c|c|c|c|c|c|c|c|}
\hline No. & P.U. & Surface P. U. (ha) & Year & s.p.u & $\begin{array}{l}\text { Infested } \\
\text { surface } \\
\text { (ha) }\end{array}$ & $\begin{array}{c}\% \text { of } \\
\text { infested } \\
\text { P. U. }\end{array}$ & Larvae $/ \mathrm{m}^{2}$ & $\begin{array}{c}\text { Infestation } \\
\text { degree }\end{array}$ \\
\hline \multirow{4}{*}{1} & \multirow{4}{*}{$\begin{array}{l}\text { P.U.I } \\
\text { Ilva }\end{array}$} & \multirow{4}{*}{4158.86} & 2010 & 18 & 106 & 2.5 & $2.1-24.6$ & W- S \\
\hline & & & 2011 & 14 & 75 & 1.8 & $1.3-6.5$ & $\mathrm{~W}-\mathrm{M}$ \\
\hline & & & 2012 & 7 & 22 & 0.5 & $1.1-2.1$ & W \\
\hline & & & 2013 & 3 & 7 & 0.2 & $1.1-1.5$ & $\mathrm{~W}$ \\
\hline \multirow{4}{*}{2} & \multirow{4}{*}{$\begin{array}{c}\text { P.U.II } \\
\text { Ilişoara }\end{array}$} & \multirow{4}{*}{4173.09} & 2010 & 22 & 120 & 2.9 & $1.6-7.9$ & $\mathrm{~W}-\mathrm{M}$ \\
\hline & & & 2011 & 17 & 69 & 1.7 & $1.6-2.2$ & W \\
\hline & & & 2012 & 10 & 35 & 0.8 & $1.5-2.7$ & $\mathrm{~W}$ \\
\hline & & & 2013 & 3 & 14 & 0.3 & $1.2-1.9$ & $\mathrm{~W}$ \\
\hline \multirow{4}{*}{3} & \multirow{4}{*}{$\begin{array}{l}\text { P.U..III } \\
\text { Neagra }\end{array}$} & \multirow{4}{*}{3634.27} & 2010 & 24 & 103 & 2.8 & $2.9-25.2$ & $\mathrm{~W}-\mathrm{S}$ \\
\hline & & & 2011 & 23 & 117 & 3.2 & $1.7-6.3$ & $\mathrm{~W}-\mathrm{M}$ \\
\hline & & & 2012 & 12 & 41 & 1.1 & $1.8-2.7$ & $\mathrm{~W}$ \\
\hline & & & 2013 & 5 & 12 & 0.3 & $1.1-1.5$ & $\mathrm{~W}$ \\
\hline \multirow{4}{*}{4} & \multirow{4}{*}{$\begin{array}{l}\text { P.U.IV } \\
\text { Sălard }\end{array}$} & \multirow{4}{*}{8721.04} & 2010 & 26 & 82 & 0.9 & $1.4-2.9$ & $\mathrm{~W}$ \\
\hline & & & 2011 & 24 & 96 & 1.1 & $1.5-2.7$ & $\mathrm{~W}$ \\
\hline & & & 2012 & 11 & 32 & 0.4 & $1.2-1.9$ & W \\
\hline & & & 2013 & 6 & 17 & 0.2 & $1.3-1.7$ & $\mathrm{~W}$ \\
\hline \multirow{4}{*}{5} & \multirow{4}{*}{$\begin{array}{c}\text { P.U.V } \\
\text { Zebrac }\end{array}$} & \multirow{4}{*}{666.11} & 2010 & 6 & 29 & 4.4 & $1.3-2.8$ & $\mathrm{~W}$ \\
\hline & & & 2011 & 5 & 33 & 4.9 & $1.8-2.2$ & $\mathrm{~W}$ \\
\hline & & & 2012 & 4 & 14 & 2.1 & $2.1-2.9$ & $\mathrm{~W}$ \\
\hline & & & 2013 & 2 & 6 & 0.9 & $1.8-2.2$ & $\mathrm{~W}$ \\
\hline \multirow{4}{*}{6} & \multirow{4}{*}{$\begin{array}{l}\text { P.U.VI } \\
\text { Gudea }\end{array}$} & \multirow{4}{*}{2919.44} & 2010 & 12 & 54 & 1.8 & $2.1-6.1$ & $W-M$ \\
\hline & & & 2011 & 10 & 51 & 1.7 & $1.2-2.5$ & $\mathrm{~W}$ \\
\hline & & & 2012 & 11 & 31 & 1.1 & $1.7-2.4$ & $\mathrm{~W}$ \\
\hline & & & 2013 & 3 & 13 & 0.4 & $1.2-1.8$ & W \\
\hline \multirow{4}{*}{\multicolumn{2}{|c|}{ TOTAL }} & \multirow{4}{*}{24372.81} & 2010 & 108 & 494 & 2.03 & $1.3-25.2$ & $W-S$ \\
\hline & & & 2011 & 92 & 441 & 1.81 & $1.2-6.5$ & W- M \\
\hline & & & 2012 & 55 & 175 & 0.72 & $1.1-2.9$ & $\mathrm{~W}$ \\
\hline & & & 2013 & 22 & 69 & 0.28 & $1.1-2.2$ & $\mathrm{~W}$ \\
\hline
\end{tabular}

$\mathrm{W}=$ weak, $\mathrm{M}=$ medium $\mathrm{S}=$ strong

compliance with those obtained by Holuša, (1999) which said that the density of emerged adults of $P$. abietina was $6.0 \pm 8.5$ specimens $/ 0.25 \mathrm{~m}^{2}$ ). Due to the application of chemical control treatments, in this year it has not been reported a strong attack on any surface. At P.U. II and P.U. III on some small areas has been reported, however, a medium intensity attack.

In 2012 the infested area was 175 ha, situated in 55 s.p.u representing $0.72 \%$ of the total forest. At the Production Unit level the infested area ranged from $0.4 \%$ (in P.U. IV) and $2.1 \%$ (in P. U.V). The larvae density ranged from $1.1 / \mathrm{m}^{2}$ to 2.9 larvae $/ \mathrm{m}^{2}$, which showes a low degree of infestation. In 2013 at the Forestry Department level it was observed the lowest level of attack of this species in the entire period of the survey.

The infested area is more declined in this year, the attack was recorded on 69 hectares, located in 22 s.p.u. which represents $0.28 \%$ of the total surface. At the level of P. U. infected area ranged from $0.2 \%$ (in P.U. IV) and $0.9 \%$ (in P.U. V). The larval density ranged between 1.1 larvae $/ \mathrm{m}^{2}$ and 2.2 larvae $/ \mathrm{m}^{2}$, which show a low 
level of infestation. In our study we found that predatory Carabidae species had a particularly important role in reducing the population density of Pristiphora abietina Christ. by consuming larvae and pupae withdrawn for the diapause. Führer et al., (2001) also afirms that predacious Carabidae are very important for the control of Pristiphora abietina Christ. cocoons exceeding the parasitic Hymenoptera species.

In the table 2 are presented the species of Carabidae which have been captured using Barber traps in the years 2010-2013. During the

Tab. 2. Carabidae species collected using Barber traps ( Lunca Bradului, 2011 - 2013)

\begin{tabular}{|c|c|c|c|c|c|c|}
\hline \multirow{2}{*}{ No. } & \multirow{2}{*}{ Species } & \multicolumn{4}{|c|}{ Year } & \multirow{2}{*}{ Tota } \\
\hline & & 2010 & 2011 & 2012 & 2013 & \\
\hline 1 & Amara aenea De Geer. & 3 & 5 & - & 1 & 9 \\
\hline 2 & Amara apricaria Payk. & 1 & - & - & 1 & 2 \\
\hline 3 & Amara eurynata Duft. & - & - & 5 & - & 5 \\
\hline 4 & Amara crenata Dej. & - & 1 & 1 & 6 & 8 \\
\hline 5 & Amara familiaris Duft. & - & 6 & - & 1 & 7 \\
\hline 6 & Amara ovata $\mathrm{F}$ & 8 & 1 & 4 & - & 13 \\
\hline 7 & Amara similata Gyll. & - & 2 & - & 7 & 9 \\
\hline 8 & Bembidion lampros Herbst. & 2 & - & - & 1 & 3 \\
\hline 9 & Brachinus crepitans L. & - & 8 & 1 & 3 & 12 \\
\hline 10 & Calathus fuscipes Goeze. & 4 & - & 3 & 5 & 12 \\
\hline 11 & Calathus metallicus Dejean & 1 & - & 2 & - & 3 \\
\hline 12 & Calosoma inquisitor $\mathrm{L}$. & 3 & 2 & 8 & 12 & 25 \\
\hline 13 & Carabus besseri Fischer & - & 3 & - & 1 & 4 \\
\hline 14 & Carabus calceatus Duft. & - & 7 & 2 & 4 & 13 \\
\hline 15 & Carabus coriaceus L. & 2 & 2 & 8 & 7 & 19 \\
\hline 16 & Carabus glabratus Payk. & 1 & - & - & 4 & 5 \\
\hline 17 & Carabus ulrichii Germar & 32 & 37 & 24 & 28 & 121 \\
\hline 18 & Carabus violaceus L. & 13 & 3 & 14 & 21 & 51 \\
\hline 19 & Cymindis humeralis Fourc. & 22 & 15 & 29 & 14 & 80 \\
\hline 20 & Cymindis vaporariorum L. & - & 2 & 6 & - & 8 \\
\hline 21 & Dromius longiceps Dejean. & - & - & 11 & 1 & 12 \\
\hline 22 & Harpalus aeneus $\mathrm{F}$. & 16 & 8 & 4 & 19 & 47 \\
\hline 23 & Harpalus azureus $\mathrm{F}$. & - & 2 & - & 1 & 3 \\
\hline 24 & Harpalus calceatus Duft. & 11 & 8 & 27 & 13 & 59 \\
\hline 25 & Harpalus distinguendus Duft. & 24 & 19 & 26 & 27 & 96 \\
\hline 26 & Harpalus griseus Panz. & 4 & 9 & - & 1 & 14 \\
\hline 27 & Harpalus pubescens Muell. & 1 & 2 & 3 & 8 & 14 \\
\hline 28 & Harpalus puncticollis Payk. & - & 8 & 2 & 1 & 11 \\
\hline 29 & Harpalus tardus Panz. & 13 & 18 & 9 & 8 & 48 \\
\hline 30 & Leistus nitidus Duft. & - & - & 4 & - & 4 \\
\hline 31 & Licinus cassideus $\mathrm{F}$ & 1 & 3 & - & 2 & 6 \\
\hline 32 & Microlestes minutulus Goeze. & - & - & 1 & 2 & 3 \\
\hline 33 & Panagaeus crux major L. & - & 2 & - & 1 & 3 \\
\hline 34 & Polystichus connexus Fourc. & 3 & - & - & - & 3 \\
\hline 35 & Pterostichus niger Schaller & 6 & - & 1 & 7 & 14 \\
\hline \multirow[t]{2}{*}{36} & Pseudoophonus rufipes Schellenberg & 1 & 1 & - & - & 2 \\
\hline & Total & 172 & 174 & 195 & 207 & 748 \\
\hline
\end{tabular}


experimental period with the help of Barber traps were collected 748 specimens of carabide belonging to 36 species. The results of the monitoring showed that in the year of 2010 was captured the lowest number of specimens (172) belonging to 22 species of Carabidae followed by the year 2011 when 174 specimens were captured belonging to 25 species of Carabidae.

In the last two years the number of specimens grew thus in 2012 the number of specimens traped was 195 and in the year 2013 was 207 belonging to 23 respectivelly 29 species of Carabidae.

Most of collected specimens in the four experimental years belong to the specie Carabus ulrichii Germar, with a total of 121 beetles, followed by the species of Harpalus distinguendus Duft. with 96 beetles and Cymindis humeralis Fourc. with 80 beetles.

The species that were captured every year were Calosoma inquisitor L., Carabus coriaceus L., Carabus ulrichii Germar, Carabus violaceus L., Cymindis humeralis Fourc., Harpalus aeneus F., Harpalus calceatus Duft., Harpalus distinguendus Duft., Harpalus pubescens Muell. and Harpalus tardus Panz.

Brudea and Pei (2006) in their study found that inyear $20042 \%$ of the autumn cocoons of Pristiphora abietina collected were attacked by chalcidoids and $21 \%$ were attacked by ichneumonids.

\section{CONCLUSION}

Following the study it was found that Pristiphora abietina Christ. is present in all the protuction units of Lunca Bradului forestry district but the infested areas were reduced.

At Forestry Department level the infested areas range from $0.28 \%$ to $2.03 \%$ of the total surface.

The numerical density of larvae withdrawn for hibernation varied from a year to another the density ranging between 1.1 and 25.2 larvae $/ \mathrm{m}^{2}$.

It is necessary to monitor the specie all over the resinous forest stands, pure or mixed, to assess population density and taking the necessary measures to control this insect pest.

With the help of Barber traps 36 species of carabid beetleswere captured.

Most of collected specimens belonged to the species Carabus ulrichii Germar, followed by species Harpalus distinguendus Duft. and Cymindis humeralis Fourc.

\section{REFERENCES}

1. Brudea V and Pei G (2006). Bioecology and control researches concerning the little spruce sawfly Pristiphora Abietina (Christ.) (Hymenoptera: Tenthredinidae), Analele Ştiinţifice ale Universităţii „AL. I. CUZA” Iaşi, s. Biologie animală, Tom LII.

2. Egger A (1989). Zur Massenvermehrung und aviochemischen Bekämpfung der Kleinen Fichtenblattwespe, Pristiphora abietina (Christ.) (Hym., Tenthredinidae) in Oberösterreich 1981-1987, Anzeiger für Schädlingskunde, Pflanzenschutz, Umweltschutz, 62:127-132.

3. Egger A (1990). Künstliche Ameisenvermehrung der Formica polyctena Foerts. (Kleine Waldameise) über Ablegerbildung in Oberösterreich, Waldhygiene, 18 (34): 65-92.

4. Führer E, Rosner S, Schmied A and Wegensteiner R (2001). Studies on the significance of pathogenic fungi in the population dynamics of the Lesser Spruce Sawfly, Pristiphora abietina Christ. (Hym., Tenthredinidae). Journal of Applied Entomology, 125, 235-242.

5. Holonec L, Cherechesiu V and Taut I (2004). Research regarding the presence of the deleterious agent Pristiphora abietina in the pine arbors outside the specific spreading area, Bulletin U.S.A.M.V. Cluj-Napoca, Horticulture, 61: 127-132.

6. Holuša J (1999). Bionomie pilatky smrkové (Hymenoptera: Tenthredinidae) na severní Morave a ve Slezsku v letech 1998-1999, Zprávy Lesnického Výzkumu, 44 (4): 19-27.

7. Holuša J and Drápela K (2006). Yellow sticky boards: a possible way of monitoring little spruce sawfly (Pristiphora abietina) (Hymenoptera: Tenthredinidae), Journal of Forest Science, 52 (1): 13-21.

8. Holuša J and Holuša O (2003). Historický prubeh výskytu a poškození smrkových porostů pilatkou smrkovou (Hymenoptera: Tenthredinidae) v České Republice, Zprávy Lesnického Výzkumu, 48 (4): 186-194.

9. Holuša J and Lubojacký J (2007). Correlation between 9. flight activity of sawflies Pristiphora abietina, P. saxesenii, $P$. gerula and P. leucopodia (Hymenoptera: Tenthredinidae) and spruce (Picea abies) bud breaking in Eastern Czech Republic, Journal of Forest Science, 53: 69-73

10. Holuša J, Liška J, Kapitola P, Peśková V and Soukup F (2005). Aspekt fitopatologiczny i entomologiczny zdrowotności świerczyn górskich na terenie Republiki Czeskiej, Leśne Prace Badawcze, 2: 133-138.

11. Holuša J, Liška J, Kapitola P, Pesková V and Soukup F (2006). The phytopathological and entomological aspects of the health of mountain Norway spruce stands in the Czech Republic, Current problems of forest protection in spruce stands under conversion. Papers from a scientific workshop held at Ustron'-Jaszowiec, Poland, 13-14 October, 1: 85-92.

12. Jonaitis V and Zajanckauskas $P$ (1973). The role of the predators of the small spruce sawfly (Lygaeonematus 
abietinus Crist) in regulating the population density of the pest, Acta Entomologica Lituanica, 2: 115-125.

13. Netherer S and Führer E (1999). Konzipierung eines Risikoschätzmodells zur Bestimmung der Prädisposition von Standorten und Beständen gegenüber Gradationen von Pristiphora abietina (Christ) (Hym. Tenthr.), Allgemeine Forst- und Jagdzeitung, 170 (3): 53-60.

14.Perepechina Yu I (2010). Effect of defoliating insect pests on the condition of forests in the southern TransUrals forest-steppe, Lesnoe Khozyaǐstvo, No. 6 pp. 45- 46.
15. Schmied A and Führer E (1996). Zur Bedeutung von Laufkäfern (Coleoptera: Carabidae) in Schadgebieten der Kleinen Fichtenblattwespe, Pristiphora abietina (Hymenoptera: Tenthredinidae), Entomologia Generalis, 21 (1/2): 81-94.

16. Tăut I, Simonca V and Holonec L (2011). Detection and prognosis defoliators Tortrix viridana and Pristiphora abietina in the northwestern Transylvania forests, Bulletin U.S.A.M.V. Cluj-Napoca, Horticulture, 68 (1): 469-473.

17.Wulf A and Schumacher J (2007). Die Waldschutzsituation 2006 in der Bundesrepublik Deutschland, Forst und Holz, 62 (1): 19-22. 